\title{
Seroprevalence for Human Cytomegalovirus in samples from dialysis and kidney transplanted patients
}

\author{
Soroprevalência do Citomegalovirus Humano em amostras de pacientes dialíticos e \\ transplantados renais \\ Seroprevalencia del Citomegalovirus Humano en muestras de pacientes en diálisis y \\ trasplantados renales
}

Patrícia Okubo ${ }^{1}$, Waldir Veríssimo da Silva Júnior ${ }^{1}$, Edna Maria Vissoci Reiche ${ }^{2}$, Miria Ramos ${ }^{1}$, Sueli Donizete

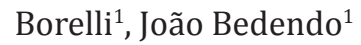

The aim of this study was at investigating the seroprevalence of Human Cytomegalovirus in dialysis and kidney transplanted patients and the association with hemodialysis and sex. It is a cross sectional study made in 2011 and 2012 in the county of Maringá, PR, Brazil. The studied population consisted of 203 dialysis patients and 53 kidney transplanted patients and the viral identification was made through serological technique. The study found 96\% (195) seropositivity for anti-HCMV IgG in dialysis patients and 100\% in the transplanted ones; $5 \%$ (10) seropositivity for anti-HCMV-IgM in dialysis patients and 37.7\% (20) in transplanted ones. Performing Fisher's exact test, there was no significant association between the seroprevalence of anti-HCMV with hemodialysis and gender. A large number of infected patients suggest the importance of nursing care to avoid cross-infection during routine procedures.

Descriptors: Dialysis; Renal Insufficiency, Chronic; Cytomegalovirus.

Objetivou-se investigar a soroprevalência do Citomegalovírus Humano em dialíticos e transplantados renais e a associação com a hemotransfusão e o sexo. Trata-se de estudo transversal, realizado nos anos de 2011 e 2012, no município de Maringá, PR, Brasil. A população estudada foi composta por 203 pacientes dialíticos e 53 transplantados renais e a identificação viral foi realizada por meio de técnica sorológica. Encontrou-se 96\% (195) de soropositividade para o anti-HCMV-IgG em dialíticos e 100\% nos transplantados; 5\% (10) de soropositividade para o anti-HCMV-IgM em dialíticos e 37,7\% (20) em transplantados. Realizando o teste exato de Fischer, não houve associação significante entre a soropositividade do antiHCMV com a hemotransfusão e o gênero. A grande parcela de infectados sugere a importância do cuidado de enfermagem para evitar a infecção cruzada durante os procedimentos de rotina.

Descritores: Diálise; Insuficiência Renal Crônica; Citomegalovírus.

El objetivo fue investigar la seroprevalencia de Citomegalovirus Humano en dialíticos y trasplantados renales y la asociación con la transfusión de sangre y el sexo. Estudio transversal, llevado a cabo de 2011 a 2012, en Maringá, PR, Brasil. La población fue compuesta de 203 pacientes dialíticos y 53 trasplantados renales y la identificación viral se realizó mediante la técnica serológica. Se encontró 96\% (195) de seropositividad para anti-HCMV-IgG en dialíticos y 100\% en los trasplantados; 5\% (10) de seropositividad para anti-HCMV-IgM en dialíticos y 37,7\% (20) en trasplantados. Realizándose la prueba exacta de Fisher, no hubo asociación significativa entre la seropositividad del anti-HCMV con la transfusión de sangre y género. A la gran parte de los infectados se señala la importancia de la atención de enfermería para prevenir la infección cruzada durante los procedimientos de rutina.

Descriptores: Diálisis; Insuficiencia Renal Crónica; Citomegalovírus.

\footnotetext{
${ }^{1}$ Universidade Estadual de Maringá. Maringá, PR, Brazil.

${ }^{2}$ Universidade Estadual de Londrina. Londrina, PR, Brazil.

Corresponding author: João Bedendo

Universidade Estadual de Maringá, Centro de Ciências da Saúde, Departamento de Enfermagem. Av. Colombo, 5790-Zona Sete. CEP: 87020900 - Maringá, PR, Brazil. E-mail: jbedendo@uem.br
} 


\section{Introduction}

The human cytomegalovirus is a DNA virus belonging to the Herpesviridae family, Betaherpesvirinae subfamily and cytomegalovirus gender, known as Human Herpes-virus Type 5, one of the main causes of morbidity and mortality in immunocompromised people $\mathrm{e}^{(1)}$, especially, bearers of chronical renal insufficiency and transplanted patient $^{(1-2)}$

Man is the only reservoir of the human cytomegalovirus and it is acquired through direct contact $^{(3)}$, in most cases the infection is asymptomatic or followed only by in specific light symptoms ${ }^{(4)}$. The activation of the viral replication occurs in immunocompromised subjects such as the HIV bearers, elderly and burned patients, subjects submitted to dialysis and chemotherapy treatment and the fetuses and newborns, due to immaturity of the immunological system ${ }^{(1,5-7)}$.

The incidence of the human cytomegalovirus in post kidney transplanted patients and the transmission occurs through the infected graft or through hemodialysis ${ }^{(8-9)}$. Among the dialysis patients the probability of hemodialysis is high, which may cause the direct contact with the human cytomegalovirus ${ }^{(6)}$.

The identification of this virus can be made through serology and/or molecular techniques. The immunological methods for presenting great sensibility and specificity became standard techniques for research and clinical applications. Among these methods, one of the most used is the microparticle enzyme immunoassay, which makes feasible the detection of specific human anti-cytomegalovirus antibodies, both for the IgM which characterizes acute infection, as well as the aIgM which characterizes the chronical infection ${ }^{(10)}$.

According to the above mentioned, a wide diagnostic screening of that infection in patients undergoing dialysis treatment and post renal transplanted ones must be made and early measures must be taken to avoid infection caused by human cytomegalovirus. So, with the objective to provide information which helps in the assistance to the health of the patient with chronical renal insufficiency, this study was proposed to identify the seroprevalence of the human anti-cytomegalovirus ( $\operatorname{IgC}$ and $\operatorname{IgM}$ ) in bearers with chronic renal insufficiency going through dialysis treatment and renal transplanted patients and evaluate the association of the human cytomegalovirus with gender and hemodialysis.

\section{Method}

It is a cross sectional study, which involved patients with chronical renal insufficiency and renal transplanted ones assisted in two sectors of dialysis in two hospitals of average size located in the county of Maringá, Paraná, Brazil. The sectors of dialysis assist the Unified Health System as well and other health plans in the county of Maringá, called the $15^{\text {th }}$ Regional Health Administration.

The approach occurred during a dialysis session and after the signing of the Free Informed Consent Form, a questionnaire was applied for the collection of information and after that the collection of peripheral venous blood for the identification of the presence of the human anti-cytomegalovirus (antiHCMV). In the two sectors of dialysis there were 370 patients, of those 290 were under hemodialysis and 80 were renal transplanted.

The criteria of exclusion of the study were: the patients refused to participate in the research; they presented difficulty of comprehension and communication; hemodynamic instability or any other complication which could impede the collection of data and venous blood and age below 18. The data were collected and processed in the years 2011 and 2012. The sample of the study consisted of 203 dialysis patients and 53 renal transplanted ones.

The detection and the characterization of the anti-HCMV (IgG and IgM) antibodies were made using the quantitative microparticle enzyme immunoassay 
method, through the commercially available kit Abbott Diagnostics AxSYM® System (Abbott Laboratories, Abbott Park, IL). This immunoenzimatic techniques use micro particles which increases the surface of contact, the sensibility and specificity and decreases the time of incubation. Values above $15 \mathrm{AU} / \mathrm{ml}$ (Units of antibodies per milliliter) were considered positive for anti-HCMV, values bellow $10 \mathrm{AU} / \mathrm{ml}$ were considered negative and the results between $10-15 \mathrm{AU} / \mathrm{ml}$ were considered as gray zone. The results defined as gray zone are interpreted as doubtful or suspect, there is, presented indeterminate result ${ }^{(11)}$. The subject were characterized as to the condition of bearer and not of anti-HCMV (IgG/IgM) the frequency of occurrence of hemodialysis was evaluated only among the dialysis patients.

The results and the collected data were tabulated in Excel ${ }^{\circledR}$ spreadsheets, generating a computerized data bank and transferred to the Statistica 7.0 software to make Fischer's exact test. This test compares two independent variables and calculates the ' $p$ ' significance directly, a ' $p$ ' below 0.05 is considered a significant co-relation and a ' $\mathrm{p}$ ' above or equals 0.05 is considered non-significant, that is, without correlation. The statistical analysis was made separately among dialysis patients and transplanted one. The results of the frequency of the anti-HCMV-IgG and IgM, and the other correlations are presented, as follows, separately for the group of patients under dialysis treatment and for the group of renal transplanted patients.

The ethical aspects were respected and the study was approved by Committee of Ethics in Research of the Universidade Estadual de Maringá, Paraná, Brazil with protocol no.534/2010.

\section{Results}

Among the 203 dialysis patients, 129 were male (63.5\%) and 74 were female (36.5\%). The average of years of age was similar in the two groups (52.6 years among the men and 51.8 years among the women). The average time of dialysis was 46.6 months for the male group and 54.1 months for the female group.

Concerning the seropositivity among the dialysis patients (Table 1), 195 (96\%) were seropositive for anti-HCMV. Among the 195 positive for anti-HCMV, 185 (94.9\%) exclusively had the antiHCMV-IgG and 10 (5.1\%) had concomitantly the anti-HCMV-IgM, that is, no patient singly presented only the acute infection. Fisher's exact test, used to correlate the frequency of anti-HCMV with gender showed a ' $p$ ' value of 0.99 for anti-HCMV-IgG and 0.92 for anti-HCMV-IgM, that is, the proportion of positivity for the anti-HCMV (IgG/IgM) is the same in both sexes.

Table 1 - Distribution of the seroprevalence of the anti-HCMV (IgG and IgM) antibodies among dialysis patients (n=203), according to gender

\begin{tabular}{|c|c|c|c|c|c|c|c|}
\hline \multirow{3}{*}{ Variable } & \multicolumn{3}{|c|}{ Result of Anti-HCMV-IgG } & \multicolumn{4}{|c|}{ Result of Anti-HCMV-IgM } \\
\hline & Positive & Negative & Total & Positive & Negative & Gray Zone & Total \\
\hline & $n(\%)$ & $n(\%)$ & $\mathbf{n}$ & $n(\%)$ & $n(\%)$ & $n(\%)$ & $\mathbf{n}$ \\
\hline \multicolumn{8}{|l|}{ Gender } \\
\hline Male & $124(96.1)$ & $5(3.9)$ & 129 & $7(5.4)$ & $118(91.5)$ & $4(3.1)$ & 129 \\
\hline Female & $71(96.0)$ & $3(4.0)$ & 74 & $3(4.1)$ & $69(93.2)$ & $2(2.7)$ & 74 \\
\hline Total n(\%) & $195(96.0)$ & $8(4.0)$ & $203(100.0)$ & $10(4.9)$ & $187(92.0)$ & $6(3.0)$ & $203(100.0)$ \\
\hline
\end{tabular}


Patients under hemodialysis treatment are prone to have hemodialysis, due to bleedings, hemolysis and coagulation in the circuit of hemodialysis. 124 (63.5\%) of the 195 bearers of the ant-HCMV-IgG and $6(60 \%)$ of 10 positive patients for anti-HCMV-IgM had gone through at least one hemodialysis. It should be highlighted that all the 10 patients bearers of anti-HCMV-IgM also presented anti-HCMV-IgG. Correlating the seropositivity of the anti-HCMV with the hemodialysis, the Fisher's exact text showed a ' $\mathrm{p}$ ' value of 0.26 for anti-HCMV-IgG and 0.71 for anti-HCMV-IgM, denoting that the presence of the virus is independent of the hemodialysis (Table 2).
The group of 53 transplanted patients consisted of 32 men (60.4\%) and 21women (39.6\%). The average age was 46.9 years in the male sex and 40.1 years in the female sex. The average time of transplant, in months, was 102.5 for men and 89.4 for women.

Table 3 shows the seroprevalence of anti-HCMV-IgG and anti-HCMV-IgM according to the gender among the renal transplanted patients. There was $100 \%$ of seropositivity in the group anti-HCMV-IgG and concomitantly $20(37.7 \%)$ were positive for the anti-HCMV-IgM. Making Fisher's exact test, correlating the presence of the antibodies with the variable gender, it showed a ' $p$ ' value of 1.00 for anti-HCMV-IgG and 0.90 para anti-HCMV-IgM, that is, the proportion of seropositivity in both genders is the same.

Table 2 - Distribution of seroprevalence of anti-HCMV (IgG and IgM) antibodies among the dialysis positive patients (195) who had or not at least one hemodialysis

\begin{tabular}{|c|c|c|c|c|c|c|c|}
\hline \multirow{3}{*}{ Variable } & \multicolumn{3}{|c|}{ Result of Anti-HCMV-IgG } & \multicolumn{4}{|c|}{ Result of Anti-HCMV-IgM } \\
\hline & Positive & Negative & Total & Positive & Negative & Gray Zone & Total \\
\hline & n(\%) & n(\%) & $\mathbf{n}$ & n(\%) & n(\%) & n(\%) & $\mathbf{n}$ \\
\hline \multicolumn{8}{|c|}{ Hemodialysis } \\
\hline Yes & $124(63.6)$ & 7 (87.5) & 131 & $6(60.0)$ & $120(64.2)$ & $5(83.3)$ & 131 \\
\hline No & $71(36.4)$ & $1(12.5)$ & 72 & $4(40.0)$ & 67 (35.8) & $1(16.7)$ & 72 \\
\hline Total $\mathrm{n}$ & 195 & 8 & 203 & 10 & 187 & 6 & 203 \\
\hline
\end{tabular}

Table 3 - Distribution of the presence of anti-HCMV (IgG and IgM) antibodies among transplanted patients (IgG and (gM) antibodies among transplanted patients

\begin{tabular}{|c|c|c|c|c|c|c|c|}
\hline \multirow{3}{*}{ Variable } & \multicolumn{3}{|c|}{ Result of Anti-HCMV-IgG } & \multicolumn{4}{|c|}{ Result of Anti-HCMV-IgM } \\
\hline & Positive & Negative & Total & Positive & Negative & Gray Zone & Total \\
\hline & n(\%) & n(\%) & $\mathbf{n}$ & $n(\%)$ & n(\%) & $n(\%)$ & $\mathbf{n}$ \\
\hline \multicolumn{8}{|l|}{ Gender } \\
\hline Male & 32 & - & 32 & 13 & 17 & 2 & 32 \\
\hline Female & 21 & - & 21 & 7 & 13 & 1 & 21 \\
\hline Total n(\%) & $53(100.0)$ & - & $53(100.0)$ & $20(37.7)$ & $30(56.6)$ & $3(5.7)$ & $53(100.0)$ \\
\hline
\end{tabular}




\section{Discussion}

In this study the seroprevalence for the anti-HCMV, for the two groups, did not present statistically significant difference regarding gender and hemodialysis. The literature reports a higher tendency of the acquisition of the virus in women ${ }^{(12)}$, once these have a greater chance of contact with infected children ${ }^{(13)}$.

The chronical infection characterized by the presence of the anti-HCMV-IgG, was found in most patients, both in those undergoing dialysis treatment as well as in renal transplanted patients. A study made in the State of Bahia, Brazil, found more than $80 \%$ of healthy subjects presenting anti-HCMV-IgG ${ }^{(13)}$.

Among the patients of the group of dialysis, there was no statistically significant difference in the seroprevalence for anti-HCMV among those who received the hemodialysis or not. Other studies did not find any association between hemodialysis and infection caused by HCMV in dialysis patients ${ }^{(14)}$. In the last years, new techniques of selection and blood clearance, as the technique of removing leucocytes, as well as a greater control of the donators have made possible the decrease of such infections ${ }^{(15)}$. Considering the knowledge, on the risk of infection by HCMV among immunosuppressed patients and keeping in mind a better care with the blood components, it is possible to justify the decrease of the rates of seroprevalence for the anti-HCMV ${ }^{(6,15)}$.

The seroprevalence of the anti-HCMV-IgM, which characterizes acute infection, was higher among the group of transplanted patient (37.7\%) than among those of the dialysis group (5\%), possibly due to the influence of the immunosuppression of the immune system in the transplanted patients, caused by the use of corticosteroid medication such as prednisone, used to avoid the graft rejection. Renal transplanted patient who are immunosuppressed have a greater probability of acute infection characterized by the presence of the anti-HCMV-IgM, than the immunocompetent population $^{(16)}$. More information will be obtained and new studies will be conducted to elucidate this result of higher frequency of anti-HCMV of renal transplanted patients. Another study shows the presence of the infection due to activated HCMV in population which presents alterations of the immune system ${ }^{(17)}$.

The seroprevalence of the anti-HCMV-IgG in this study among transplanted patients was $100 \%$ and it was not possible to evaluate if there was an activation of the latent infection by HCMV or if these received the organs already infected, once it was not possible to obtain the data of seroprevalence in the period prior to the transplant. Besides that, we did not evaluate the correlation of the frequency of the anti-HCMV between the group of transplanted patients who are immunosuppressed and some immunocompetent group. The screening for transplant involves the search of signs and symptoms of infection by HCMV both in the donator as well as in the receiver. The most serious symptoms of the viral infection in post-operative are observed in seronegative receivers and seropositive donators (approximately 60\%), which makes the penetration of other agents easier, as bacteria and fungi(16).

Undetermined results obtained (gray zone) for anti-HCMV-IgM ( 6 blood dialysis patients and 3 transplanted patients), must be repeated with the use of other methods of identification for the confirmation of the diagnosis.

\section{Conclusion}

96\% of seropositivety was found for anti-HCMV-IgG in dialysis patients and $100 \%$ in the renal transplanted ones, showing the high morbidity by the HCMV in this population, and there is no correlation between the hemodialysis and the sex with the seroprevalence of the anti-HCMV. Thus, it is important to evaluate the forms of transmission of the HCMV and verify the real risk of the transmission of the HCMV through hemodialysis to seropositive and seronegative subjects and define strategies of selection. Besides that, new studies in the population are necessary to confirm, or not, these findings. 
This study presented some limitations, such as the lack of data in the pre-renal transplant and in the beginning of blood dialysis (bearer or not of the HCMV); the population studied does not represent the total number of renal patients assisted in the region, once there are other services that were not included in the study; refusals of some patients to participate, loss due to other reasons such as hemodynamic instability and age bellow 18 years, besides undetermined results observed.

Therefore, the importance of precaution in the invasive procedures in the patients should be reinforced, such as washing hands, the use of gloves, and the use of aseptic technique in invasive procedures in the adequate maintenance of the blood dialysis, in order to avoid infections and clinical alterations. The nursing team must render adequate care in order to pursuit the physical and emotional welfare of the client, which goes far beyond the execution of the procedures. Consequently, the client can lead a healthy life with better quality, avoiding abandoning the treatment and its complications.

\section{Acknowledgments}

To the microbiology and immunology laboratory team of the Universidade Estadural de Maringá, Paraná, Brazil; and to the Hospital Casa da Misericórdia and the Clínica do Rim nursing team, both in the county of Maringá.

\section{Collaborations}

Okubo P contributed for the conception of the article, data collection, analysis, interpretation of the data and writing of the article. Silva Júnior WV was responsible for the tabulation and statistical analysis. Reiche EMV and Ramos M contributed for the processing and identification of the samples collected. Borelli SD and Bedendo J participated in the construction of the project, revision, writing and critical analysis of the article.

\section{References}

1. Testal AG, Díaz PO, Escobar BAB, Criado-Álvarez JJ, Plumed J.Análisis de infección por citomegalovirus y sus consecuencias en el trasplante: revisión de uma década. Med Clin. 2011; 137(8):335-9.

2. Roso CC, Beuter M, Bruinsma JL, Silva JH, Timm AMB, Pauletto MR. Clinical aspects of people with chronic renal failure in conservative treatment. Rev Rene. 2013; 14(6):1201-8.

3. Tavares MV, Domingues AP, Tavares M, Malheiro E, Tavares F, Moura P. Citomegalovírus existe lugar para o rastreio durante a gravidez? Acta Med Port. 2011; 24(supl 4):1003-8.

4. Oliveira FL, Braga A, Caputo A, Rezende-Filho JF, Montenegro CAB. Infecção pelo citomegalovírus na gestação: uma visão atual. Femina. 2011; 39(11):515-9.

5. Bordes J, Gaillard T, Maslin J, Esnault P, Goutorbe P, Brisou P. Cytomegalovirus infection monitored by quantitative real-time PCR in critically ill patients. Crit Care. 2011; 15(2):412.

6. Mendrone Junior A. Prevalência da infecção pelo citomegalovírus: a importância de estudos locais. Rev Bras Hematol Hemoter. 2011; 32(1):7-8.

7. Rafailidis PI, Mourtzoukou EG, Varbobitis IC, Falagas ME. Severe cytomegalovirus infection in apparently immunocompetent patients: a systematicreview. Virol J. 2008; 27(5):47.

8. Matos SB, Meyer R, Lima FWM. Citomegalovírus: uma revisão da patogenia, epidemiologia e diagnóstico da infecção. Rev Saúde Com. 2011; $7(1): 44-57$.

9. Díaz-Betancur J, Henao JE, Jaimes FA. Efectos de la infección y la enfermedad por citomegalovirus en receptores de trasplante renal. Acta Med Colomb. 2012; 37(3):131-7.

10. Araújo PRB, Ferreira AW. High diagnosticefficiency of IgM-ELISA withthe use of multipleantigenpeptides (MAP1) from T. gondii ESA (SAG-1, GRA1 and GRA-7) in acute toxoplasmosis. Rev Inst Med Trop São Paulo. 2010; 52(2):63-8.

11. Hackett DJ, Zhang C, Stefanescu C, Pass RF. EnzymeLinked Immunosorbent Assay for Measurement of Cytomegalovirus Glycoprotein B Antibody in Serum. Clin Vaccine Immunol. 2010; 17(5):836-9. 
12. Gkrania-Klotsas E, Langenberg C, Sharp SJ, Luben, R, Kay-Tee K, Wareham NJ. Seropositivity and Higher Immunoglobulin G antibody levels Against Cytomegalovirus are associated with mortality in the population-based European prospective investigation of Cancer-Norfolk Cohort. Clin Infect Dis. 2013; 56(10):1421-7.

13. Matos SB, Meyer R, Lima FWM. Seroprevalence of cytomegalovirus infection among healthy blood donors in Bahia State, Brazil. Rev Bras Hematol Hemoter. 2010; 32(1):45-9.

14. Wu Y, Zou S, Cable R, Dorsey K, Tang Y, Hapip CA. Direct assessment of cytomegalovirus transfusiontransmitted risks after universal leukoreduction. Transfusion. 2010; 50(4):776-86.
15. Ministério da Saúde (BR). Secretaria de Atenção à Saúde. Departamento de Atenção Especializada. Guia para o uso de hemocomponentes. Brasília: Ministério da Saúde; 2008.

16. Ono G. Guia de condutas em infecção e doença por citomegalovírus em transplante de rim e rim/pâncreas 2010. Grupo de Infecção em Transplante de Órgãos Sólidos- Escola Paulista de Medicina [Internet] 2010 [citado 2014 28 fev]. Disponível em: http://xa.yimg.com/ $\mathrm{kq} /$ groups/16781130/1397437026/name/ CMV+protocolo+2010_+HRIM_HSP.pdf

17. Görzer I, Kerschner H, Redlberger-Fritz M, Puchhammer-Stöckl E. Human cytomegalovirus (HCMV) genotype populations in immunocompetent individuals during primary HCMV infection. J Clin Virol. 2010; 48(2):100-3. 